\title{
Welding fumes control in the shipyard
}

\begin{abstract}
Welding is a process used extensively in the shipbuilding and ship repair industry. Welding fumes contain base metal and any coatings present on the base metal. The most common control measures are ventilation and respiratory protection.

Welders wear a respiratory protection and use local exhaust ventilation in enclosed and confined spaces in the ships and in the yard. Current study was conducted to determine a necessity of using a respirator along with local exhaust ventilation in a partially open space in a production area in the yard. Having this purpose air samples were taken and local exhaust ventilation was tested.

One welder was surveyed while he was welding mild steel. The results showed elevated levels of beryllium and manganese in the breathing zone. Continue wearing respiratory protection and using local exhaust ventilation while welding in this particular location was strongly recommended.
\end{abstract}

Volume 4 Issue 3 - 2016

\section{Zhanna Shorman}

USA

Correspondence: Zhanna Shorman, USA,

Email zhanna.shorman@gmail.com

Received: March 08, 2015 | Published: April 07, 2016

\section{Introduction}

Welding fumes consist of various metallic oxides produced by heated metals and its coatings. According to ACGIH, 1986, eighteen different substances have been measured in the fumes resulting from the welding of mild steel. Excessive exposure to the ingredients of welding fumes could cause different health problems, mostly metal fever with flu-like symptoms. In addition to the metal fever, welders can develop other disorders:

a. Beryllium is considered as a human carcinogen by National Toxicology Program (NTP); can cause lung cancer, noncancerous lung granulomas; sensitization; chronic beryllium disease; eye, upper respiratory, and skin irritation; contact dermatitis; heart failure and kidney stones

b. Manganese can cause neurobehavioral dysfunctions, Parkinsonism Bowler RM et al., ${ }^{1}$ described neuropsychological abnormalities observed in industrially exposed men, former and current welders. ${ }^{3}$ There is a study done by James MA et al., ${ }^{2}$ about manganese in welding fumes and potential neurological. ${ }^{2}$ The same author published an article in 2004 about pulmonary response to the welding fumes. ${ }^{3}$

To control overexposure to the welding fumes, proper ventilation has to be used as an engineering measure ${ }^{4,5}$ and a respirator has to be worn as personal protective equipment. This particular surveyed location was situated in the open air but was covered with a high rise roof and had a wall from one side. It was "partially" an open space with natural ventilation. However, considering the wall in a relatively close proximity to the welding, the respiratory protection along with local exhaust ventilation use was recommended.

Coppus Ventair blowers were used to provide local exhaust ventilation. The 6" duct was placed at the 6" distance from the welding spot.
The welder was working at the distance of 98 inches from the wall, welding the mild steel and wearing half-face air purifying respirator with P100 filters (Assigned Protection Factor, APF, 10). The survey was broken down into three parts because of different conditions of the performed task (Figure 1) and the sampling monitors' fast overloading.

The first part of the welding was done inside the cylinder with the ventilation duct placed farther than 6" from the welding. The second part of the study was done on the same cylinder but the duct was hooked up closer to the welding. The third part's samples were taken while another cylinder was welded; the ventilation duct was placed at a distance 6" and the natural wind could go through the cylinder (Figure 1).

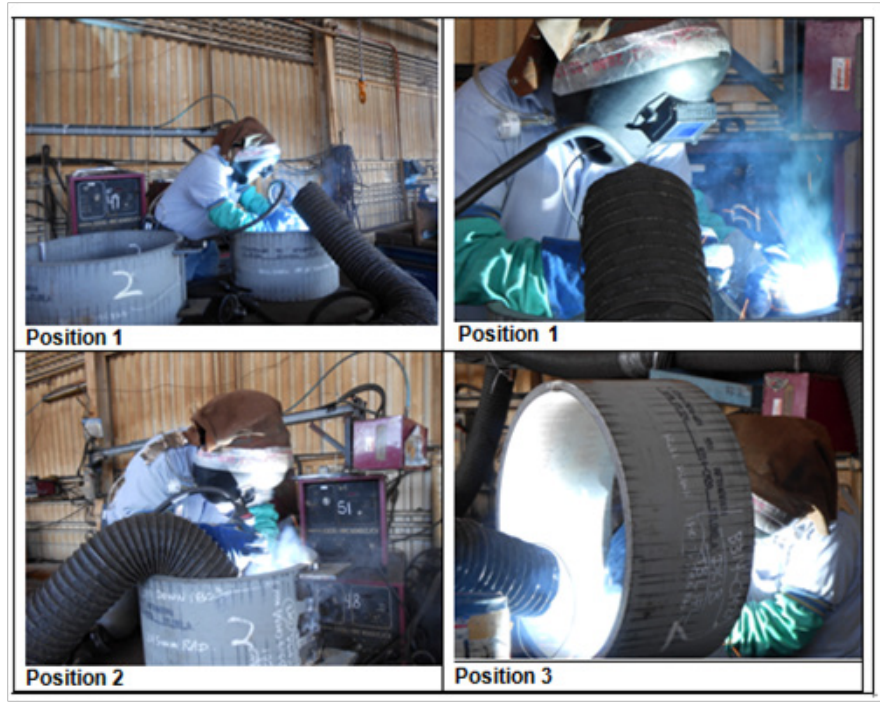

Figure 1 Attachment: Photographs of different local exhaust ventilation positions. 


\section{Methods and calculations}

\section{Air sampling methods}

The monitored worker was asked to implement his standard work practices, standard personal protective equipment and standard engineering controls. Potential employee exposure to airborne contaminants was evaluated using the standardized sampling methods listed below. Sampling pumps were used to draw air through sample media located in the employee's breathing zone. The sample media and field blanks were submitted to and analyzed by Galson Laboratories, Inc., East Syracuse, NY, which is accredited by the American Industrial Hygiene Association (AIHA).

\section{Air sampling equipment calibration}

The sampling pumps were calibrated before and after the survey with a Mini-Buck Calibrator. The Mini-Buck is a primary standard that is factory calibrated on an annual basis, and is traceable to National Institute of Standards and Technology (NIST) standards. If a difference was observed between pre- and post-survey calibrations, the average was used in determining sample volumes. If the difference between the pre- and post-survey calibrations varies by more than $5 \%$ (of the higher value), the sample is considered invalid. The calibration results for this survey's equipment were within acceptable limits.

\section{Air sampling calculations}

Since in the current survey multiple samples were collected during a single work operation, the TWA8 concentration was calculated using the following equation (OSHA Technical Manual, Personal Sampling for Air Contaminants):

$\mathrm{TWA} 8=(\mathrm{S}(1) * \mathrm{~T}(1))+(\mathrm{S}(2) * \mathrm{~T}(2))+\ldots+(\mathrm{S}(\mathrm{n}) * \mathrm{~T}(\mathrm{n})) 480$ minutes

Where $S(1), S(2), \ldots S(n)$ ) are the sample concentrations for the individual samples, and $\mathrm{T}(1), \mathrm{T}(2), \ldots \mathrm{T}(\mathrm{n}))$ are the sample times, in minutes, for the individual samples.

\section{Ventilation measurement methods}

Ventilation measurements were taken using a TSI, Velocicalc, Model 9555P Velometer.

Table I Standardized Sampling Methods
On an annual basis, the Velometer is returned to TSI for its recommended calibration. The calibration standards used by TSI are traceable to National Institute of Standards and Technology (NIST) standards.

\section{Discussion}

Breathing zone air sampling was used to measure weld fume exposure on one worker, during manual MIG welding. Three samples for 21 metals were taken over the shift. The obtained results were analyzed against CalOSHA Permissible Exposure Limit (PEL) and OSHA PEL. The results are presented in the Table 1.

The survey showed that the 8-hours TWA concentration of manganese and beryllium exceeded 2.3 times CalOSHA PELs but were under the OSHA PELs. Analysis of the obtained results showed that the 8 -hours TWA levels of beryllium $\left(0.000475 \mathrm{mg} / \mathrm{m}^{3}\right)$ and manganese $\left(0.453344 \mathrm{mg} / \mathrm{m}^{3}\right)$ outside of respirator. Beryllium is a known human carcinogen; manganese is considered as a factor causing severe neurobehavioral dysfunction.

The local exhaust ventilation test showed that the airflow and the velocity in the 6" duct were good to provide a capture velocity $172 \mathrm{fpm}$ at the 6" distance. CalOSHA requires capture velocity for welding fumes at least $100 \mathrm{fpm}$.

As it was mentioned in the Flynn MR and Susi's ${ }^{6}$ paper published in the Annual Occupational Hygiene "Although LEV can produce significant fume reductions, work practices are important and training in correct hood positioning, as well as avoiding the plume, is necessary." The study results showed clearly that the air concentrations of all metals were higher in the position 1 when the duct was positioned farther away. In term to provide effective ventilation the welders have to be trained in proper use of local exhaust ventilation in welding process.

The welder was protected from overexposure since he was wearing the air purifying respirator with APF 10; also, he was using local exhaust ventilation while welding which absorbed most of the fume (Table 2) (Table 3).

\section{Pump type Sample media Air contaminants 2I metals: $\quad$ Analytical method}

\begin{tabular}{|c|c|c|c|c|c|}
\hline \multirow{8}{*}{ Gilian5000 } & \multirow{8}{*}{ 37mm MWMCE } & & & Nickel & \multirow{8}{*}{ NIOSH 7300/mod, OSHA } \\
\hline & & Aluminum & Chromium & Potassium & \\
\hline & & Antimony & Cobalt & Selenium & \\
\hline & & Arsenic & Copper & Selenium & \\
\hline & & Barium & Iron Oxide & sodum & \\
\hline & & Beryllium & Lead & Vanadium & \\
\hline & & Cadmium & Magnesium & Vanadium & \\
\hline & & Calcium & Manganese & & \\
\hline
\end{tabular}


Table 2 Air Contaminant Sampling Results

Sample Concentration, $\left(\mathrm{mg} / \mathrm{m}^{3}\right)$

\begin{tabular}{|c|c|c|c|c|c|c|c|}
\hline $\begin{array}{l}\text { Activity } \\
\text { description PPE } \\
\text { engineering } \\
\text { control }\end{array}$ & $\begin{array}{l}\text { Air } \\
\text { contaminant }\end{array}$ & $\begin{array}{l}\text { Duration } \\
80 \text { minutes } \\
\text { (from } \\
7.35 \text {-through } \\
9.00 \text { ) }\end{array}$ & $\begin{array}{l}\text { Duration } \\
90 \text { minutes } \\
\text { (from } \\
9.15 \text {-through } \\
10.45 \text { ) }\end{array}$ & $\begin{array}{l}\text { Duration } \\
\text { 65minutes } \\
\text { (from II.45- } \\
\text { through } \\
\text { 13.00) }\end{array}$ & $\begin{array}{l}\text { 8-hrTWA } \\
\text { exposure } \\
\left(\mathrm{mg} / \mathrm{m}^{3}\right)\end{array}$ & $\begin{array}{l}\text { Cal/OSHA } \\
\text { permissible } \\
\text { exposure limit } \\
(\mathrm{PEL}) \text { 8-hrTWA } \\
\left(\mathrm{mg} / \mathrm{m}^{3}\right)^{*}\end{array}$ & $\begin{array}{l}\text { OSHA } \\
\text { permissible } \\
\text { exposure } \\
\text { limit (PEL) } \\
\text { 8-hrTWA (mgl } \\
\text { m }^{3} \text { ) }\end{array}$ \\
\hline \multirow{19}{*}{$\begin{array}{l}\text { Manual welder } \\
\text { Thermal arc / } \\
\text { MIG welder. } \\
\text { Welding wire: } \\
\text { MIL 7II-ICHY, } \\
\text { E24403/ID, } \\
0.035 \text { ". } \\
\text { Respiratory } \\
\text { protection: } \\
3 \text { M } 7503 \text { half- } \\
\text { face air purifying } \\
\text { respirator; PI00 } \\
\text { cartridges } \\
\text { Ventilation: } \\
\text { Local exhaust } \\
\text { ventilation 6" duct }\end{array}$} & Aluminum & 0.1 & $6.70 \%$ & $<0.058$ & $<0.037083$ & 5 & 15 \\
\hline & Antimony & 0.15 & $<0.0050$ & $<0.0069$ & $<0.026872$ & 0.5 & 0.5 \\
\hline & Arsenic & $<0.0019$ & $<0.0017$ & $<0.0023$ & $<0.000947$ & $1.00 \%$ & 0.01 \\
\hline & Barium & $<0.00094$ & $<0.00083$ & $<0.0012$ & $<0.000475$ & $50.00 \%$ & 0.5 \\
\hline & Beryllium & $<0.00094$ & $<0.00083$ & $<0.0012$ & $<0.000475$ & $0.02 \%$ & 0.002 \\
\hline & Cadmium & $<0.00094$ & $<0.00083$ & $<0.0012$ & $<0.000475$ & $1 \%$ & 0.005 \\
\hline & Calcium & $<0.47$ & $<0.42$ & $<0.58$ & $<0.235625$ & 2 & \\
\hline & Chromium & $<0.047$ & $<0.042$ & $<0.058$ & $<0.023563$ & 0.5 & \\
\hline & Cobalt & $<0.0028$ & $<0.0025$ & $<0.0035$ & $<0.001409$ & 0.02 & 0.1 \\
\hline & Copper & 0.016 & $1.60 \%$ & 0.0098 & $0.70 \%$ & 0.1 & \\
\hline & Iron Oxide & 8.5 & 4.2 & 1.5 & $240.73 \%$ & 5 & 10 \\
\hline & Lead & 0.0033 & $0.23 \%$ & $<0.0029$ & $<0.001374$ & 0.05 & 0.05 \\
\hline & Magnesium & 0.73 & $26.00 \%$ & $<0.058$ & $<0 .|7827|$ & 10 & \\
\hline & Manganese & 1.7 & $88.00 \%$ & 0.037 & $45.33 \%$ & 0.2 & 5 ceiling \\
\hline & Nickel & 0.027 & 0.0047 & 0.0035 & $0.59 \%$ & 0.5 & I \\
\hline & Potassium & I.I & 0.34 & $<0.12$ & $<0.263333$ & 2 & \\
\hline & Thallium & $<0.0094$ & $<0.0083$ & $<0.012$ & $<0.004748$ & 0.1 & 0.1 \\
\hline & Vanadium & $<0.0028$ & $<0.0025$ & $<0.0035$ & $<0.001409$ & 0.05 & \\
\hline & Zinc Oxide & 0.16 & 0.24 & 0.087 & 0.083448 & 5 & 5 \\
\hline
\end{tabular}

Footnotes: Units of $\mathrm{mg} / \mathrm{m}^{3}$ indicate milligrams of contaminant per cubic meter of air.

*Cal/OSHA Title 8, Section 5I55, Table ACI.

A sample result with a "<" sign indicates that there was no contaminant detected with the detection limit shown.

Table 3 Local Exhaust Ventilation test

\begin{tabular}{lllll}
\hline Date & Time & $\begin{array}{l}\text { Duct velocity, } \\
\text { fpm }\end{array}$ & $\begin{array}{l}\text { Airflow, } \\
\text { cfpm }\end{array}$ & $\begin{array}{l}\text { velocity at } \\
\text { 6” distance, } \\
\text { fpm }\end{array}$ \\
\hline 12:44:06 & 2360 & 463.31 & 171.825 \\
& $12: 45: 05$ & 2291 & 449.8 & 171.825 \\
\hline
\end{tabular}

\section{Acknowledgements}

None.

\section{Conflict of interest}

The author declares no conflict of interest.

\section{References}

1. Bowler RM, Gysens S, Diamond E, et al. Neuropsychological sequelae of exposure to welding fumes in a group of occupationally exposed men. Int J Hyg Environ Health. 2003;206(6):517-529.

2. Antonini JM, Santamaria AB, Jenkins NT, et al. Fate of manganese associated with the inhalation of welding fumes: Potential neurological effects. Neurotoxicology. 2006;27(3):304-310.

3. Antonini JM, Taylor MD, Zimmer AT, et al. Pulmonary Responses to Welding Fumes: Role of Metal Constituents. J Toxicol Environ Health. 2004;67(3):233-249. 
4. Pouzou JG, Warner C, Neitzel RL, et al. Confined Space Ventilation by Shipyard Welders: Observed Use and Effectiveness. Ann Occup Hyg. 2015;59(1):116-121.

5. Han-Qing Wang, Chun-Hua Huang, Di Liu, et al. Fume transports in a high rise industrial welding hall with displacement ventilation system and individual ventilation units. Building and Environment. 2012;52:119-128.
6. Flynn MR, Susi P. Local Exhaust Ventilation for the Control of Welding Fumes in the Construction Industry-A Literature Review. Ann Occup Hyg. 2012;56(7):764-776. 